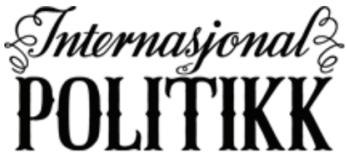

\section{Militær aktivisme uden politisk handling. Mod en ny forståelse af aktivisme i dansk udenrigs- og sikkerhedspolitik inspireret af Hannah Arendt}

\author{
Jakob Dreyer* \\ Københavns Universitet, Danmark \\ Christine Nissen \\ Dansk Institut for Internationale Studier, Danmark
}

\begin{abstract}
Aktivisme bruges hyppigt blandt forskere og praktikere som en "overordnet etikette på dansk udenrigspolitik" (Pedersen \& Ringsmose, 2017, s. 339). Der er ikke konsensus om, hvornår Danmark blev aktivistisk, eller om etiketten passer lige godt på alle områder af udenrigspolitikken. Ikke desto mindre er der bred enighed om, at Danmarks militære engagement i de seneste årtier, herunder særligt deltagelsen i Irak- og Afghanistan-krigene, udgør et højdepunkt i dansk aktivisme. Vores analyse diskuterer og nuancerer denne karakteristik ved at formulere en alternativ forståelse af politisk aktivisme inspireret af Hannah Arendts politiske teori. Med vores konceptualisering gentænker vi centrale begreber i litteraturen - initiativ, risiko og deltagelse - og sondrer mellem militært engagement og egentlig politisk aktivisme. Ud fra denne begrebslige ramme genbesøger vi Danmarks krigsdeltagelse i 2000'erne. Vi argumenterer for, at dansk udenrigspolitik, selv hvad angår krigsdeltagelsen, har været reaktiv, risikoavers og med begrænset folkelig forankring og derfor mindre
\end{abstract}

\footnotetext{
^Kontaktinformasjon: Jakob Dreyer, e-post: Jakob.Dreyer@ifs.ku.dk 
aktivistisk, end litteraturen hidtil har antaget. Ved at fjerne den aktivistiske etikette forsøger vi at rejse nye spørgsmål om, hvad udenrigspolitisk aktivisme fremadrettet kan og bør være.

\section{Nøgleord: udenrigspolitik • sikkerhedsstudier • krig • international politik $\cdot$ politisk teori}

\section{Introduktion ${ }^{\mathrm{I}}$}

Da USA kaldte, sagde Danmark hurtigt ja til at bidrage militært til invasionen af Irak i 2003. I Afghanistan kæmpede danske soldater ved frontlinjen i Helmandprovinsen. Og i 2011 besluttede Folketinget enstemmigt med få dages varsel at sende bombefly til Libyen. Sammenlignet med sine nordiske naboer og andre småstater i Europa, har Danmark i de seneste årtier vist stor villighed til at udsende militære bidrag til farlige, internationale operationer. Dette "særkende" er i den eksisterende litteratur om dansk udenrigs- og sikkerhedspolitik blevet brugt til at kategorisere Danmark som aktivistisk (se bl.a. Mariager \& Wivel, 2019; Wivel, 2005, 2013; Pedersen, 2012; Olesen, 2012; Kristensen, 2013; Jakobsen, 2015, 2019) ${ }^{2}$. Et gennemgående argument i "aktivismeforskningen" (Jakobsen, 2019) har i forlængelse heraf været, at krigsdeltagelsen er udtryk for udenrigspolitisk engagement, initiativlyst og risikovillighed (Pedersen \& Ringsmose, 2017, s. 345; Pedersen \& Gram-Skjoldager, 2015).

Trods forskelle er litteraturen således bundet sammen af spørgsmålet: hvorfor er dansk udenrigspolitik aktivistisk? Formålet med denne artikel er at udfordre litteraturens præmis ved at diskutere to underliggende spørgsmål: hvad er udenrigspolitisk aktivisme? Og er dansk udenrigspolitik i forlængelse heraf aktivistisk? Vi formulerer således en teoretisk funderet "problematiserende genbeskrivelse" af dansk udenrigsog sikkerhedspolitik ud fra en antagelse om, at "etiketter" er med til at forme deskriptive og normative forskningsdagsordener (Shapiro, 2009, s. 201-3). I denne genbeskrivelse benytter vi Hannah Arendts begreb om politisk handling til at diskutere, hvad politisk aktivisme er, og hvordan det adskiller sig fra militær aktivisme. Ud fra denne sondring argumenterer vi for, at dansk udenrigspolitik, selv i forbindelse med krigsdeltagelsen i 2000'erne, har været mere reaktiv, risikoavers og passiv og dermed mindre aktivistisk end aktivismelitteraturen har antaget.

\footnotetext{
${ }^{1}$ Vi vil gerne takke Ole Wæver, Anders Wivel, Minda Holm samt to anonyme reviewers for meget brugbare kommentarer til tidligere versioner af denne artikel. Ligeledes en stor tak til Marius Hauge Hvithamar for højt kvalificret feedback og forskningsassistance.

${ }^{2}$ At der er stor konsensus om denne karakteristik, afspejles også i Det Sikkerhedspolitiske Barometer, der er baseret på et survey omfattende højtstående ansatte i centraladministrationen, Forsvaret og erhvervslivet samt politikere, forskere og meningsdannere. I de seneste fem årlige udgivelser har ca. 90 procent af respondenterne svaret, at Danmark gennem de seneste 20 år "i høj grad" har haft en aktivistisk udenrigs- og sikkerhedspolitik (Breitenbauch, Jakobsen \& Kristensen, 2018).
} 
Vi udfolder argumentet og dets implikationer i tre dele. Den første del kortlægger forskellene mellem aktivisme som hidtil beskrevet i aktivismelitteraturen og forståelsen, vi udvikler af begrebet med udgangspunkt i Hannah Arendts politiske teori. Vi fokuserer på demokratisk deltagelse og forholdet mellem politik og vold, herunder sondringen mellem risiko og deltagelse på et politisk-strategisk og et militært, operativt og taktisk niveau. I anden del genbesøger vi Danmarks militære engagement efter Den Kolde Krigs afslutning med fokus på krigene i Irak og Afghanistan. Sidste del diskuterer kort vilkårene for dansk aktivisme fremadrettet.

\section{Mod en ny forståelse af politisk aktivisme}

Man kan inden for aktivismelitteraturen finde tre hovedforklaringer på Danmarks krigsdeltagelse i 2000erne (se Pedersen \& Gram-Skjoldager, 2015; Mariager \& Wivel, 2019; Wivel, dette Fokusnummer). Første forklaring argumenterer for, at det danske, militære engagement i Irak og Afghanistan brød med tidligere international aktivisme forankret i multilateralisme (Knudsen, 2004). Et brud, der forklares med udgangspunkt i forholdet til USA som garant for dansk sikkerhed. Med Irak- og Afghanistankrigene blev Danmark i dette perspektiv en offensiv, militær-strategisk aktør, der valgte side i voldelige konflikter (Rynning, 2003; Petersen, 2010). Den anden tilgang bygger på en bredere forståelse af udenrigspolitiske interesser og forklarer aktivismen ud fra et dansk ønske om information, indflydelse og anerkendelse fra USA (Breitenbauch, 2015; Pedersen, 2019). Hvor skiftende regeringer i 1990'erne også tilstræbte tilpasning til USA's udenrigspolitik med deltagelse i fredsbevarende operationer på Balkan nåede vægtningen af forholdet til USA et historisk højdepunkt under Fogh-regeringerne i 00'erne (Mouritzen, 2007). Den tredje forklaring fokuserer på strategisk kultur og analyserer aktivismen som en videreførelse af en længerevarende internationalisme, der kan føres tilbage til starten af det 20. århundrede. Den Kolde Krigs afslutning muliggiorde i dette perspektiv, at Danmark kunne øge sine internationale aktiviteter, hvilket efter 11 . september 2001 tog en mere militaristisk form, men fortsat byggede på et værdibaseret engagement i verdens konflikter (Holm, 1997; Wivel, 2013, 2014; Rasmussen, 2005).

Foruden disse tre hovedlæsninger af dansk aktivisme i de seneste årtier debatteres det i litteraturen, hvorvidt den militære aktivisme i sig selv udgør kernen i aktivismen, eller om den blot er ét område, der er ligestillet med andre politikområder såsom økonomi, diplomati og udvikling (Pedersen \& Ringsmose, 2017; Dreyer, 2017). Der er fra dette perspektiv ikke konsensus om, hvorvidt Danmark, hvad angår diplomati, udviklingspolitik og økonomi i FN- og EU-regi, også har ageret aktivistisk (Andersen, 2019; Engberg-Petersen, 2018; Wivel, 2017). Trods disse uenigheder og nuancer er der dog bred enighed om, at krigsdeltagelsen i 2000 'erne er et centralt eksempel på dansk aktivisme.

Pedersen og Ringsmose har formuleret det seneste, mest sammenhængende og eksplicitte bud på en definition af aktivisme, som ifølge dem er "preget af initiativlyst, 
engagement og vilje til at udnytte muligheder og skabe forandringer $i$ de internationale omgivelser. Også når der er risici forbundet med den førte politik" (Pedersen \& Ringsmose, 2017, s. 345). Definitionen er relevant her, da den afdækker centrale antagelser, som aktivismeforskningen deler: At aktivisme skal ses i kontrast til en passivistisk tilgang, og at Danmark efter Den Kolde Krig, og særligt i bidragene til de amerikansk ledede krige i Afghanistan og Irak, har ageret aktivistisk (Pedersen \& Ringsmose, 2017; Ringsmose \& Rynning, 2017). For at nuancere begrebet yderligere "kompartmentaliserer" ovennævnte definition aktivismen. Derved kan Danmark i denne definition være mere eller mindre aktivistisk på det militære, politisk/diplomatiske og økonomiske område (Pedersen \& Ringsmose, 2017, s. 345; Ringsmose \& Rynning, 2017). Den militære aktivisme, som er genstandsfelt i nærværende artikel, kan ifølge dem vurderes ud fra, hvor mange menneskelige og økonomiske ressourcer et land anvender i internationale militære operationer, og hvor risikable missionerne er (Pedersen \& Ringsmose, 2017, s. 347).

En central antagelse i Ringsmose og Rynnings definition er koblingen mellem deltagelse i internationale militære operationer og aktivisme. Denne kobling mellem voldsanvendelse og politik kan genfindes blandt mange ellers forskelligartede politiske teoretikere fra Thomas Hobbes, over Otto Hintze og Max Weber til Frantz Fanon. Mest relevant for denne diskussion er Carl von Clausewitz' berømte dictum, at krig er fortsættelsen af politik med andre midler (Clausewitz, 2010). Clausewitz argumenterede her for, at politik var det første hensyn i krig, og at anvendelsen af vold udgjorde et middel underlagt politiske mål (Clausewitz, 2010; Dimitriu 2018). Vi forfægter ikke, at krig er et politisk fænomen som sådan, men vi problematiserer her antagelsen om, at deltagelse i krig i sig selv udgør politisk aktivisme.

Her bygger vores aktivismeforståelse på Hannah Arendt, hvis politiske teori sondrer mellem krig og andre former for voldsanvendelse på den ene side og politisk handling på den anden. Hvor aktivismelitteraturen sætter lighedstegn mellem politisk aktivisme og deltagelse i krig, og Clausewitz forstår voldsanvendelse i krig som et middel til at opnå politiske mål, anskuer Arendt egentlig politisk aktivisme som ikke-voldelig. Krig kan godt være forbundet med politisk aktivisme, men det vurderes ikke ud fra anvendelsen af militære midler, men hvordan krig retfærdiggøres politisk. Sondringen giver i vores øjne en mere præcis forståelse af, hvad politisk aktivisme er, og passer til en demokratisk politikforståelse, der på den ene side anerkender, at politik er en hård og til tider kynisk magtkamp, men samtidig fastholder et ideal om politisk aktivisme som ikke-voldelig og skabende. For at udfolde argumentet vil de følgende afsnit kort skitsere Hannah Arendts teori om politisk handling.

\section{Arendts aktivisme}

Hannah Arendts politiske teori er svær at sætte i en entydig ideologisk boks, men forbindes typisk med en republikansk, pluralistisk og anti-totalitær tradition. Hun skrev sine hovedværker i kølvandet på Anden Verdenskrig, hvor Arendt selv var flygtet fra det nazistiske Tyskland til USA. I lyset af krigene og den efterfølgende konsolidering 
af elitedrevne, bureaukratiske massedemokratier i Vesten fokuserede hendes arbejde på, hvordan man i denne kontekst kunne bevare et rum for politisk handling (Kalyvas, 2008). Baseret på sin analyse af totalitarismens fremvækst op til og under krigen forsøgte hun at genfinde en præmoderne politisk teori baseret på en (idealiseret) forståelse af den græske bystat inspireret af Sokrates og Aristoteles.

Udgangspunktet for Arendts politiske forståelse er i forlængelse heraf, at mennesker i fællesskaber er i stand til at skabe politisk forandring. "What makes man a political being is his faculty of action: It enables him to get together with his peers, to act in concert, and to reach out for goals and enterprises that would never enter his mind, let alone the desires of his heart, had he not been given this gift to embark on something new" (Arendt, 1970, s. 82). Politik er således tæt knyttet til menneskets evne til at tænke kreativt og skabe forandring $\mathrm{i}$ tale og handling ud fra en pluralistisk antagelse om menneskelig frihed og forskellighed. Frihed og forskellighed indebærer her ikke blot, at vi har præferencer og kan vælge mellem forskellige valgmuligheder, men at vi er i stand til at handle og derved skabe uforudsigelig forandring i politiske fællesskaber (Lang \&Williams, 2008, s. 7). Ifølge Arendt opstår det politiske rum "whenever men are together in the manner of speech and action" (Arendt, 2018, s. 199). I forlængelse heraf centrerer hendes politikforståelse sig om deltagelse i et fællesskab, hvor ideer udveksles. Disse fællesskaber var ikke konsensusprægede, tværtimod udgjorde uenighed og konflikt en drivende politisk kraft (Owens, 2008, s. 42-45; d'Entrèves, 2019). Rummet for denne aktivisme er ikke givet eller permanent, men begrænses i lukkede, bureaukratiske og topstyrede samfund med lavt politisk engagement (Kalyvas, 2008).

Selvom Arendt analyserede politisk vold - herunder militærmagt - som et vigtigt politisk fænomen, anså hun vold som væsensforskelligt fra politisk handling og som et udtryk for det politisk fællesskabs sammenbrud. Politisk handling opstår gennem sproget, mens vold er ude af stand til at tale og derfor ikke udgør politisk handling i sig selv (Arendt, 2018, s. 26; Arendt, 1970; Owens, 2008, s. 15-16). Arendt ikke var pacifist, og hun mente, at politisk anvendelse af vold kunne legitimeres under særlige omstændigheder, men at den politiske handling udgøres af voldens legitimering og formål og ikke i selve voldsudøvelsen.

\section{Dansk militæraktivisme genbesøgt}

Dansk aktivisme defineret som præget af initiativlyst, udnyttelse af muligheder og risikovillighed synes umiddelbart i overensstemmelse med Hannah Arendts politikforståelse. Går vi mere i detaljen kommer markante forskelle dog til syne.

\section{Initiativ og forandring}

Initiativ- og forandringslyst fremhæves bredt $\mathrm{i}$ aktivismelitteraturen som bærende elementer $\mathrm{i}$ en aktivistisk udenrigs- og sikkerhedspolitik. Som det kortlægges i den eksisterende litteratur om dansk aktivisme og senest grundigt dokumenteret i krigsudredningen (Mariager \& Wivel, 2019), er Danmark ofte parat til at deltage 
i internationale militære operationer. Dette mønster har gjort sig gældende i hvert fald siden Danmarks aktive indsatser på Balkan i 1990'erne, hvilke blev efterfulgt af indsatserne i Afghanistan fra 2001, Irak fra 2003 og igen fra 2014, Libyen-indsatsen i 2011 og senest i Sahel-regionen fra 2013 (Mariager \& Wivel, 2019; Jakobsen \& Møller, 2012; Nissen, 2018).

Parathed til at deployere militære styrker udgør fra en Arendtsk læsning dog ikke i sig selv initiativ- og forandringsvillighed. Det afhænger af omstændighederne for den politiske beslutning. Ser man nærmere på Wivel og Mariagers analyse af Danmarks krigsdeltagelse, skete de ikke på dansk initiativ, men imødekom en større allieret magts forespørgsel. Et lille land som Danmark "spiller dog sjeldent en afgørende rolle $i$ beslutningen om ivarkscettelsen af et internationalt militert engagement eller $i$ engagementets videre forløb, såsom cendringer $i$ engagementets mål (...) eller afslutning” (Mariager \& Wivel, 2019, s. 83-4). Det fremgår, at Danmarks militære engagement ikke har haft betydning for de overordnede operationer, men reaktivt imødekom andres initiativ (Mariager \& Wivel, 2019). I en Arendtsk forståelse underbygger udredningen således, at Danmarks militære engagement ikke var initiativrigt eller forandringssøgende udadtil, men reaktivt, og således ikke ativistisk.

Det er dog også relevant at forholde sig til, om udenrigspolitikken indadtil kan karakteriseres som aktivistisk. I 2003 og 2006 valgte Anders Fogh Rasmussenregeringen at bidrage til henholdsvis Irak-invasionen uden FN-mandat og NATO's træningsmission i Irak med et snævert folketingsflertal (Ringsmose \& Rynnig, 2017). Centralt for legitimeringen af særligt Irak-krigen i 2003 var et opgør med Danmarks samarbejdspolitik under Anden Verdenskrig og Fodnotepolitikken i NATO-regi i 1980 'erne. Beslutningen udløste stor offentlig debat og undergravede ifølge kritikere internationalismens multilaterale og humanitære principper (Knudsen, 2004). Dette opgør udgjorde en form for indenrigspolitisk initiativ og forandringslyst, som kan betragtes som udtryk for politisk aktivisme også i et Arendtsk perspektiv. Det er dog væsentligt at tilføje her, at Irakkrigen på mange måder ikke udgjorde normen i Danmarks internationale operationer. Med undtagelse af de to afstemninger har der været brede flertal bag dansk krigsdeltagelse både før og efter Anders Fogh Rasmussen. Under Libyen-interventionen var der ligefrem enstemmighed, mens øvrige missioner har haft bred opbakning, herunder fra de to store regeringsbærende partier, Socialdemokratiet og Venstre (Ringsmose \& Rynning, 2017; Mariager \&Wivel, 2019; Jakobsen \& Møller, 2012). Set indadtil kan man således argumentere for, at særligt Irakkrigen udgjorde en form for indenrigspolitisk aktivisme. Denne indenrigspolitiske konflikt, som kunne indikere en forandringsvillig udfordring af status quo, er dog en undtagelse i dansk udenrigspolitik, som er blevet afløst af en tiltagende norm om konsensus (Jakobsen, 2019).

\section{Ressourcer og risiko}

Ifølge Pedersen og Ringsmose kan graden af militær aktivisme vurderes ud fra de "samlede ressourcer (menneskelige og økonomiske), som staten investerer $i$ de vabnede 
styrkers deltagelse i internationale operationer" (2017, s. 347). I denne forståelse er ressourcerne, såvel som de militære risici soldater udsættes for, således udtryk for politisk aktivisme i sig selv. Fra dette perspektiv er det et udtryk for aktivisme, at Danmark udsendte store militære bidrag til operationer med relativt store tab sammenlignet med både dansk tradition og sammenlignelige lande (Pedersen \& Ringsmose, 2017). Ideen om, at aktivisme således kan kvantificeres, så større anvendelse af det militære instrument udgør et mål for politisk aktivisme, står i kontrast til Arendts forståelse af politisk handling. Fra dette perspektiv udelukker deltagelse i internationale militære operationer ikke aktivisme, men er heller ikke en "garanti" herfor. Her er det relevant at sondre skarpere mellem risiko på et operativt og taktisk niveau i militære operationer og politisk-strategisk risiko. På et taktisk niveau udsættes soldater for fysiske og mentale risici forbundet med fysisk vold. Her er der ingen tvivl om, at Danmarks militære engagement var forbundet med meget store risici og tab (Jakobsen \& Ringsmose 2015). Men risikoen på et politisk-strategisk niveau, som ledende politiske aktører, officerer og embedsmænd står overfor i en moderne, demokratisk kontekst, er af en anden natur. Her er risikoen forbundet med, at politisk handling er uforudsigelig og irreversibel. Der er for politiske aktører derfor særlig risiko forbundet med at søge at skabe politisk forandring og tage ansvar $i$ et politisk fællesskab.

Set i det lys er spørgsmålet, om dansk krigsdeltagelse i Irak og Afghanistan var forbundet med særlige politiske ressourcer og risici? Var der en risiko for, at den førte politik kunne fejle? Og hvem ville i så fald stå til ansvar? Sådanne spørgsmål har dog været genstand for yderst begrænset debat. Det kan skyldes, at målet med det militære engagement var Danmarks renommé blandt alliancepartnere snarere end krigenes udfald. Som PeterViggo Jakobsen lidt polemisk har formuleret det: "Vi går i krig for at være med. Og hvis USA og England er glade, når vi tager hjem, har vi vundet" (Jakobsen i Jensen, 2010; Henriksen \& Ringsmose, 2011). Denne forklaring stemmer overens med udredningens konklusion om, at Danmark hverken initierede eller i nævneværdig grad påvirkede krigenes udfald, men søgte at imødekomme særligt USA. Igen adskiller Arendt sig fra defensive realistiske analyser af dansk aktivisme, for hvem overlevelse er det altoverskyggende hensyn. Det politiske fællesskabs overlevelse er naturligvis en forudsætning for politisk handling, men sikring af fællesskabets overlevelse er kun en nødvendig, men ikke tilstrækkelig forudsætning for politisk aktivisme. Egentlig politisk aktivisme rækker udover ren overlevelse i et forsøg på at forandre Verden.

Tilgangen blandt danske beslutningstagere kan ud over med det alliancepolitiske hensyn også forklares med udviklingen af en maksimalistisk strategisk kultur hos den politiske elite kendetegnet ved en "vilje til at forsvare de fundamentale verdier og principper, som understøtter statens eget politiske system og dets allierede" (Ringsmose \& Rynning, 2017, s. 405). En strategisk kultur, der er blevet "som en ncesten integreret del af nationens kollektive identitet." (Ringsmose \& Rynning, 2017, s. 418). Som en konsekvens heraf ses militære operationer som en moralsk forpligtelse i sig selv, hvorved 
regeringen ikke i samme grad skal stå til regnskab for krigenes begrundelse, forløb eller udfald. Dette står i kontrast til Danmarks større allierede USA og Storbritannien, hvor Afghanistan- og Irakkrigene haft stor negativ påvirkning på Tony Blair og George Bushs regeringers eftermæler (Coates \& Krieger, 2009; Jacobson, 2010).

Disse pointer understreger, at dansk aktivisme i et Arendtsk perspektiv ikke har været forbundet med store risici eller ressourcer i politisk forstand. Udadtil udgjorde deltagelsen et mål i sig selv, og den daværende regering stod i begrænset omfang til regnskab for krigene. Indadtil har krigene grundet den voksende konsensus om den maksimalistiske strategiske kultur gjort det mindre politisk risikabelt og dermed aktivistisk at fastholde det militære engagement end at formulere en alternativ politisk retning.

\section{Folkelig forankring}

Vores Arendt-inspirerede forståelse af politisk aktivisme tillægger folkelig deltagelse og åbenhed selvstændig betydning for vurderingen af graden af aktivisme. Dette involverer både graden, hvormed den politiske proces er tilgængelig for offentligheden og befolkningens engagement heri. En udbredt forklaring i aktivismeforskningen på dansk udenrigs- og sikkerhedspolitiks bæredygtighed er, at der er konsensus om linjen og stor kompromisvillighed blandt en snæver, eksklusiv gruppe af ressourcestærke aktører. Denne gruppe udgøres af ministre og ledende embedsmænd, officerer samt forskningsmiljøer, der primært finansieres af forsvarsmidler (Jakobsen, 2019). Krigsudredningen konkluderer ligeledes, at "en meget snæver kreds af ministre, topembedsmænd og officerer" (Mariager \& Wivel, 2019, s. 355) udformede Danmarks militære bidrag. Først efter en ofte månedlang dialog mellem allierede, centraladministrationen og Forsvaret, hvor indholdet i et potentielt militært engagement blev udformet, orienteredes Det Udenrigspolitiske Nævn umiddelbart forud for fremlæggelsen af den formelle beslutning. Udredningen tilføjer sågar, at skiftende regeringer har haft en minimalistisk informationspraksis med et "vist spillerum for, hvad regeringen finder er væsentlig information, som bør tilgå nævnet" (Mariager \& Wivel, 2019, s. 354).

Et fællestræk for Danmarks store krigsengagementer på Balkan, i Afghanistan og Irak er således, at bidragene formes over længere tid i en lille lukket kreds repræsenteret af regeringen, embedsværk og de væbnede styrker. Folketinget, offentligheden og partier, der ikke tilhører forligskredsen, har i den proces hverken indsigt eller mulighed for at påvirke beslutningen (Wivel, Mariager \& Mortensen, 2018; Mariager \& Wivel, 2019). Således er betingelserne for folkelig forankring meget begrænsede, hvilket fra et Arendtsk perspektiv i sig selv underminerer karakteristikken af dansk udenrigs- og sikkerhedspolitik som aktivistisk.

Udover at politikken formes af en snæver, elitær kreds, er demokratisk deltagelse i udenrigs- og sikkerhedspolitikken begrænset. Dette understreges i surveyundersøgelser, der konkluderer, at udenrigs- og sikkerhedspolitik er perifert placeret på den danske befolknings politiske radar. Meningsmålinger både fra krigsdeltagelsen 
i 2000'erne og senere har vist, at blot omkring 5\% i den danske befolkning anså krigsdeltagelsen, udenrigs- eller sikkerhedspolitikken som et af de tre vigtigste politiske emner for dem (Holstein, 2014; Friislund, 2010; Holm, 2018). Ud fra et ideal om, at bredt forankret demokratisk deltagelse er væsentligt for politisk aktivisme, kan dette ligeledes karakteriseres som et passivistisk træk ved dansk udenrigs- og sikkerhedspolitik. En relevant kritik af spørgsmålet om folkelig forankring er, om det er at sætte barren for politisk aktivisme for højt? Om udenrigspolitik, særligt når det kommer til krig, realistisk set kan være åben og borgernær? Inddragelsen af folkelig forankring er dog i overensstemmelse med Hannah Arendts forståelse af politisk handling, og det er i vores anvendelse af begrebet heller ikke et problem, at politisk aktivisme ikke er et hverdagsfænomen. Aktivisme kan i stedet anskues som et værdigt udenrigspolitisk ideal, selvom man må forvente, at aktivisme udgør undtagelsen snarere end reglen, ikke mindst når småstater involverer sig i internationale konflikter. Man kan ligeledes omvendt spørge, om aktivisme i konteksten af moderne demokratier ikke bliver for udhulet som begreb, hvis folkelig forankring og åbenhed ikke inddrages.

\section{Tilbage til aktivismen}

Vores artikel har problematiseret aktivismelitteraturens antagelse om, at dansk udenrigs- og sikkerhedspolitik er aktivistisk med udgangspunkt i to spørgsmål. Hvad er udenrigspolitisk aktivisme? Og er Danmark aktivistisk? Hvad det første angår, har vi med inspiration fra Hannah Arendts begreb om politisk handling argumenteret for, at aktivisme kan vurderes ud fra engagement, risikovillighed og folkelig forankring, og at man her skal sondre mellem politisk aktivisme og militært engagement. Vi har derved problematiseret antagelsen om, at deltagelse i internationale militære operationer i sig selv er udtryk for udenrigspolitisk aktivisme.

Selvom Danmark er hurtig og ofte gavmild, når det besluttes at sende et bidrag til en international operation, er der dog først tale om egentlig aktivisme, når der formuleres et selvstændigt, politisk mål for brug af disse ressourcer, der rækker udover ren overlevelse. Det er sjældent tilfældet i en dansk sammenhæng, hvor det ses som et mål i sig selv at udsende styrker uafhængigt af det militære engagements udfald på jorden. Selvom de mange tragiske tab af danske soldaters liv viser, at det militære engagement har været forbundet med store personlige risici for de udsendte, er dette heller ikke i sig selv udtryk for risici på et politisk-strategisk niveau. Tværtimod har den voksende konsensus blandt ledende beslutningstagere giort det mindre risikabelt at fastholde det militære engagement end at formulere en eksplicit, selvstændig strategi for dansk udenrigs- og sikkerhedspolitik. Konsensus bygger på, at dansk udenrigs- og sikkerhedspolitik styres af et pragmatisk og defensivt mål om at tilpasse sig de internationale magtforhold af hensyn til national sikkerhed snarere end på at skabe international forandring.

Danmarks beslutningsprocesser for udsendelse af militære styrker er desuden karakteriseret ved begrænset folkelig forankring. At det militære engagement formes 
af en snæver elite med begrænset inddragelse af Folketinget eller folkeligt engagement, understreger, at dansk udenrigspolitik ikke er funderet i en pluralistisk, åben, politisk proces og heller ikke i den forstand kan karakteriseres som aktivistisk. Dansk udenrigspolitik synes derfor mere reaktiv, risikoavers og passiv og dermed mindre aktivistisk, end aktivismelitteraturen har antaget.

For at Danmark kan leve op til "etiketten" politisk aktivisme vil det kræve, at politiske aktører formulerer og søger at opnå politisk risikable udenrigs- og sikkerhedspolitiske mål. Ligeledes skal den politiske praksis i højere grad forankres i Folketinget og befolkningen, hvad angår udenrigs- og sikkerhedspolitik i almindelighed og i særdelehed, når vi beder soldater om at gå i krig på Danmarks vegne.

\section{Om forfatterne}

Jakob Dreyer, Ph.d.-studerende, Institut for Statskundskab, Københavns Universitet, Jakob.Dreyer@ifs.ku.dk.

Christine Nissen, Ph.d., Researcher, Dansk Institut for Internationale Studier, chni@diis.dk.

\section{Referencer}

Andersen, L. R. (2019). The UN - a forgotten cornerstone in Danish foreign policy. I K. Fischer \& H. Mouritzen (Red.), Danish foreign policy yearbook 2019 (s. 99-130). København: DIIS.

Arendt, H. (1970). On violence. New York: Houghton Mifflin Harcourt.

Arendt, H. (2018). The human condition (2. Udg.). Chicago: University of Chicago Press. (opr. udg. 1958).

Breitenbauch, H. Ø., Jakobsen, M. B. \& Kristensen, K. S. (2018). Sikkerhedspolitisk barometer: CMS Survey 2017. Center for Militære Studier, Københavns Universitet.

Coates, D. \& Krieger, J. (2009). The mistake heard round the world: Iraq and the Blair legacy. I T. Casey (Red.), The Blair legacy (s. 247-259). London: Palgrave Macmillan.

d'Entrèves, M. P. (2019). Hannah Arendt. I E. N. Zalta (Red.), The Stanford encyclopedia of philosophy (Fall 2019 edition).

Dreyer, J. (2017). Danmarks udenrigs- og sikkerhedspolitiske strategi - less is more. Udenrigs, 2017(3), 56-61.

Dimitriu, G. (2018). Clausewitz and the politics of war: A contemporary theory. Fournal of Strategic Studies, 43(5), 645-685.

Engberg-Pedersen, L. (2018, 10. december). Danmarks fald fra udviklingstinderne: Flygtninge, migranter og udviklingsbistand. DIIS.

Friislund, M. (2010, 16. november). Vælgerne: Velfærd er vigtigst. Berlingske.

Henriksen, A. \& Ringmose, J. (2011). Hvad fik Danmark ud af det? Irak, Afghanistan og forholdet til Washington. DIIS Report 2011:14. København: DIIS.

Holm, H.-H. (1997), Denmark's active internationalism: Advocating international norms with domestic constraints. I B. Heurlin \& H. Mouritzen (Red.), Danish foreign policy yearbook 1997 (s. 52-80). København: DUPI.

Holm, T. A. (2018, 14. juni). En splinterny måling afslører danskernes vigtigste dagsorden: „Det er formentlig den mulighed, Socialdemokratiet har for at vinde næste valg". Berlingske.

Hobbes, T. (2016). Thomas Hobbes: Leviathan (Longman library of primary sources in philosophy). New York; Routledge. (org. udg. 1651).

Holstein, E. (2014, 27. oktober). Måling: Udlændingepolitik vigtigere end økonomi. Altinget.

Jacobson, G. C. (2010). George W. Bush, the Iraq War, and the election of Barack Obama. Presidential Studies Quarterly, 40(2), 207-224. 


\section{Militer aktivisme uden politisk handling}

Jensen, J. V. (2010 29. oktober). I krig med eliten. Weekendavisen 29.

Jakobsen, P. V. (2015). Danmarks militære aktivisme fortsætter med eller uden USA. Politik, 18(4), 5-13.

Jakobsen, P. V. (2019). Policy-fællesskaber, standard-og krisestyringsprocedurer: det oversete institutionelle grundlag for den brede opbakning til Danmarks aktivistiske udenrigspolitik1. Politica, 51(2), $139-167$.

Jakobsen, P. V. \& Kjærsgaard, K. (2017). Den danske FN-aktivismes storhed og fald 1945-2016. Politica: Tidsskrift for Politisk Videnskab, 49(4), 377-400.

Jakobsen, P.V. \& Møller, K. J. (2012). Good news: Libya and the Danish way of war. I N. Hvidt \& H. Mouritzen (Red.), Danish foreign policy yearbook 2012 (s. 106-130). København: DIIS.

Jakobsen, P. V., \& Ringsmose, J. (2015). In Denmark, Afghanistan is worth dying for: How public support for the war was maintained in the face of mounting casualties and elusive success. Cooperation and Conflict, 50(2), 211-227.

Kalyvas, A. (2008). Democracy and the politics of the extraordinary. Cambridge: Cambridge University Press.

Knudsen, T. B. (2004). Denmark and the war against Iraq: Losing sight of internationalism? I P. Carlsen \& H. Mouritzen (Red.), Danish foreign policy yearbook 2004 (s. 49-90). København: DIIS).

Kristensen, K. S. (Red.). (2013). Danmark i krig: demokrati, politik og strategi i den militcere aktivisme. København: Jurist-og Økonomforbundets Forlag.

Lang, A. F., Jr. \& Williams, J. (Red.) (2008). Hannah Arendt and international relations: Readings across the lines. New York: Palgrave Macmillan.

Mariager, R. M. \& Wivel, A. (2019). Hvorfor gik Danmark $i$ krig? Uvildig udredning af baggrunden for Danmarks militcere engagement $i$ Kosovo, Afghanistan og Irak. København: Københavns Universitet.

Mouritzen, H. (2007), Denmark's super Atlanticism. Fournal of Transatlantic Studies, 5(2), $155-67$.

Nissen, C. M. S. (2018). Choosing the EU with an opt-out:The europeanisation of Danish security policy and conflict management. FS \& P Ph.D. afhandlinger. Roskilde: Roskilde Universitet.

Olesen, M. R. (2012). Two Danish activist foreign policies? Changing perceptions of threat and 'activism' in Danish foreign policy 1988-2011. DIIS Report 2012:16. København: DIIS.

Owens, P. (2008). Hannah Arendt, violence, and the inescapable fact of humanity. I Lang, A. F. Jr. \& J. Williams (Red.), Hannah Arendt and international relations (s. 41-65). New York: Palgrave Macmillan.

Pedersen, R. B. (2012). Danish foreign policy activism: Differences in kind or degree? Cooperation and Conflict, 47(3), 331-349.

Pedersen, R. B. \& Gram-Skjoldager, K. (2015). International aktivisme i dansk udenrigspolitik 2001-2009. En tværfaglig forskningsstatus. Historisk Tidsskrift, 115(1).

Pedersen, R. B., \& Ringsmose, J. (2017). Aktivisme i dansk udenrigspolitik: Norden, FN, NATO og EU. Politica: Tidsskrift for Politisk Videnskab, 49(4), 163-188.

Petersen, N. (2010) Hinsides Den Kolde Krig: Danmarks internationale ordenspolitik 1990-2009. I R. Mariager, R. Schmidt \& C. Due-Nielsen (Red.), Nye fronter i den kolde Krig (s. 339-361). København: Gyldendal.

Rasmussen, M. V. (2005). 'What's the use of it?': Danish strategic culture and the utility of armed force. Cooperation and Conflict, 40(1), 67-89.

Ringsmose, J. \& Rynning, S. (2017). Rutsjebane: udsving og udfordringer i Danmarks NATO aktivisme. Politica: Tidsskrift for Politisk Videnskab, 49(4), 401-425.

Rynning, S. (2003). Denmark as a strategic actor? Danish security policy after 11 september. I P. Carlsen \& H. Mouritzen (Red.), Danish foreign policy yearbook 2003 (s. 23-46). København: DIIS.

Shapiro, I. (2009). The flight from reality in the human sciences. Princeton University Press.

von Clausewitz, C. (2010). Om krig. Aarhus: Aarhus Universitetsforlag. (org. udg. 1832).

Wivel, A. (2005). Between paradise and power: Denmark's transatlantic dilemma. Security Dialogue, 36(3), 417-421.

Wivel, A. (2013). Danmarks militære aktivisme. I Kristensen, K. S. (Red.), Danmark i krig: demokrati, politik og strategi $i$ den militere aktivisme. København: Jurist-og Økonomforbundets Forlag.

Wivel, A. (2014). Still living in the shadow of 1864? Danish foreign policy doctrines and the origins of Denmark's pragmatic. I N. Hvidt \& H. (Red.), Danish foreign policy yearbook 2014. København: DIIS.

Wivel, A. (2017). Aktivistisk med forbehold? Danmark, EU og den amerikanske verdensorden. Politica: Tidsskrift for Politisk Videnskab, 49(4), 426-450.

Wivel, A., Mariager, R. M. \& Mortensen, C. L. K. (2018, 26. juni). Denmark at war: Patterns and developments in Denmark's military engagement. Small states and the new security environment, Háskóli Íslands, Reykjavik, Island. Hentet 9. april 2020 fra http://ams.hi.is/wp-content/uploads/2018/06/Denmark-at-War-Patternsand-Developments-in-Denmark $\%$ C2\%B4s-Military-Engagement.pdf 


\section{Abstract in English \\ Military Activism Without Political Action? \\ Towards a New Conception of Activism in Danish Foreign and \\ Security Policy Inspired by Hannah Arendt}

Activism is frequently used by researchers and practitioners alike as "a general label on Danish foreign policy" (Pedersen \& Ringsmose, 2017, p. 339, authors' translation). There is no consensus as to when Denmark became activist or if the label is equally fitting to all foreign policy issue areas. However, there is broad agreement that the military engagements in recent decades, particularly the wars in Afghanistan and Iraq, constitute a high point in Danish activism. Our analysis challenges and nuances this characterization by exploring an alternative understanding of political activism inspired by Hannah Arendt's political theory. Our alternative concept of activism revisits the central elements of activism; initiative, risk and participation, and distinguishes between military engagement and political activism. Drawing on this conceptual framework, we revisit Denmark's war engagements focusing on Iraq and Afghanistan in the 2000s. We argue that from a political perspective even Denmark's war engagements have been reactive, risk averse, and with limited popular anchorage, and are therefore, less activist than hitherto argued. By tearing off the activist label we aim to revitalize the discussion about what Danish Foreign and Security policy can and should be at a time when such questions have rarely had more relevance.

Keywords: foreign policy $\bullet$ political theory $\bullet$ security studies $\bullet$ war $\bullet$ international relations 